\title{
The effect of progesterone on uterine fluid ph \& endometrial nhe-1 protein expression in rats
}

\author{
Salleh Naguib ${ }^{1 *}$, Vivi Noryati Ahmad $^{1}$, Norfadila Kasim ${ }^{1}$, Salim Muhammad Amri ${ }^{2}$, Yeong Soh \\ Onn ${ }^{2}$
}

${ }^{1}$ Department of Physiology, University of Malaya, Lembah Pantai, Kuala Lumpur, Malaysia;

*Corresponding Author: naguibsalleh@um.edu.my

${ }^{2}$ Department of Anatomy, University of Malaya, Lembah Pantai, Kuala Lumpur, Malaysia.

Received 26 October 2010; revised 25 November 2010; accepted 24 December 2010

\section{ABSTRACT}

A precise regulation of the uterine fluid volume and $\mathrm{pH}$ is essential for a successful embryo implantation. Progesterone has been reported to participate in uterine fluid volume regulation during this period, however its effect on the uterine fluid $\mathrm{pH}$ is unknown. As endometrial fluid absorption has been proposed to occur secondary to sodium $\left(\mathrm{Na}^{+}\right)$absorption under progesterone mediated effect, we therefore hypothesize that there may be a concomitant changes in fluid volume and $\mathrm{pH}$ if sodium-hydrogen exchanger (NHE), a protein responsible for both luminal $\mathrm{Na}^{+}$absorption and $\mathrm{H}^{+}$extrusion is involved. In view of these, our study aimed to investigate the possibility that progesterone affect the uterine fluid $\mathrm{pH}$ and endometrial NHE expression. Ovariectomised female SpragueDawley (SD) rats were treated with peanut oil (vehicle), oestradiol-3-benzoate and progesterone for three consecutive days. On the fourth day, in-vivo uterine perfusions were performed on anaesthetized rats. The collected perfusate were analyzed for the changes in $\mathrm{pH}$. The effect of amiloride, a non-specific $\mathrm{Na}^{+}$-channel blocker on the $\mathrm{pH}$ was investigated. The expression of uterine NHE-1 protein was detected by Western blotting and immunohistochemistry. Our findings indicate that the fluid $\mathrm{pH}$ is the lowest in progesterone-treated group and amiloride administration significantly increased the $\mathrm{pH}$ in the same treatment group ( $p<0.05)$. NHE-1 proteins were significantly expressed in the progesterone-treated group. In conclusion, progesterone induces a reduction of the uterine fluid $\mathrm{pH}$ and is amiloride-sensitive. The up-regula- tion of NHE-1 under a common progesterone effect may explain the role of this exchanger in regulating the uterine fluid $\mathrm{pH}$.

Keywords: Progesterone; Uterine-Fluid pH; NHE-1; Endometrium

\section{INTRODUCTION}

Implantation is a complex process that requires a precise control of the uterine fluid volume, $\mathrm{pH}$ and its composition. It occurs within a limited period following fertilization known as the implantation window period [1]. During this period, a reduction of the uterine luminal fluid volume has been documented in both rodents $[2,3]$ and primates [4]. Multiple molecular mechanisms such as the increased expression of pinopodes [5], aquoporins channels $[6,7]$ and the membrane $\mathrm{Na}^{+}$channel such as the epithelial $\mathrm{Na}^{+}$channel $(\mathrm{ENaC})[8]$ have been proposed to play a role in fluid movements across the endometrium under a common progesterone mediated effect [9].

Since long ago, uterine luminal fluid has been observed to contain a high amount of $\mathrm{HCO}_{3}^{-}$as compared to plasma [10]. Apical $\mathrm{HCO}_{3}^{-}$transporters such as cystic fibrosis transmembrane regulator (CFTR) [11] and the bicarbonate- chloride exchanger $\left(\mathrm{HCO}_{3}^{-} / \mathrm{Cl}^{-}\right)$ $[12,13]$ may be involved in luminal $\mathrm{HCO}_{3}^{-}$extrusion. A continuous $\mathrm{HCO}_{3}^{-}$extrusion should be followed by a concomitant $\mathrm{H}^{+}$extrusion to maintain a normal intracellular $\mathrm{pH}$ [14]. In many absorptive and secretory epithelia where $\mathrm{HCO}_{3}^{-}$extrusion occur, such as in the proximal tubule of the nephron [15], pancreatic duct [16] and epididymis [17], apical NHE plays an important role in maintaining a normal intracellular $\mathrm{pH}$.

Despite of the reported alkalinity of the uterine luminal fluid, the changes of the $\mathrm{pH}$ under different sex steroids 
effect and the underlying mechanism involved in uterine fluid $\mathrm{pH}$ regulation is not fully understood. As sex-steroids in particular progesterone play an important role in regulating uterine luminal fluid volume, we speculate that this hormone may as well affect the $\mathrm{pH}$ of this fluid. Although $\mathrm{ENaC}$ has been proposed to be involved in $\mathrm{Na}^{+}$absorption and therefore concomitant $\mathrm{H}_{2} \mathrm{O}$ absorption $[8,18]$, however NHE may be an alternative route for $\mathrm{Na}^{+}$ absorption which can create osmotic gradient to drive $\mathrm{H}_{2} \mathrm{O}$ movement across the epithelia. Additionally NHE may also be involved in the uterine fluid $\mathrm{pH}$ regulation as similar observations has been made in rats' kidney [19] and epididymis [17] as well as in the intestines of rabbits [20] and mice [21]. Therefore, the aim of this study is to investigate the effect of sex-steroids on uterine fluid $\mathrm{pH}$ as well as on the expression of NHE proteins.

\section{METHODS}

\subsection{Animals and Hormone Treatments}

Adult Wistar rats weighing 200-250 g were maintained under 12:12 lighting conditions, with free access to food and water. Ovariectomies were performed under isofluorane anesthesia to eliminate the effect of endogenous steroids. Ovariectomies were normally performed at least 10 days before initiating any hormone treatment. Steroids were dissolved in peanut oil and injected sub-cutaneously in a volume of $0.1 \mathrm{ml}$. Steroid treatment involved daily injections of $0.2 \mathrm{~g}$ oestradiol and $4 \mathrm{mg}$ progesterone for 3 consecutive days. Vehicle treated animals (control) received 3 daily injections of peanut oil. Oestradiol-3-benzoate and progesterone were purchased from Sigma-Aldrich.

\subsection{Uterine Perfusion}

The rats were anesthetized with intraperitoneal injection of $0.1 \mathrm{ml}(80 \mathrm{mg} / \mathrm{kg})$ ketamine and $0.15 \mathrm{ml}(10 \mathrm{mg} /$ $\mathrm{kg}$ ) xylazine $\mathrm{HCl}$ and maintained under anesthesia on a thermo-statically controlled heat pad for the duration of the experiment. Body temperature was monitored using a rectal thermometer. At the end of the perfusion period, the animals were killed. All procedures were approved by a local ethic committee. Uterine perfusion was achieved after tying in place fine-bore polythene tubing (ID 0.38 $\mathrm{mm}$; OD $1.09 \mathrm{~mm}$ ), pre-filled with perfusate, in both the anterior and cervical ends of the uterine horn. The cannula had minimal insertion into the lumen but had slightly heat-flared endings to prevent them being expelled by any ongoing uterine contractions. A syringe-driven infusion pump (Harvard Apparatus) was used to deliver perfusion medium (with and without amiloride) into the anterior cannula at a constant rate of $1.5 \mathrm{l} / \mathrm{min}$. The composition of the perfusion medium was based on published data on the composition of rat uterine fluid that contained low $\mathrm{Na}^{+}$ and high $\mathrm{K}^{+}$concentrations [22-24]. It consisted of: (mmol/l) $110 \mathrm{NaCl}, 14.3 \mathrm{NaHCO} 3,1 \mathrm{NaHPO} 4$ (total $\mathrm{Na}^{+}$ 125.3), $15 \mathrm{KCl}, 0.8 \mathrm{MgSO} 4,1.8 \mathrm{CaCl} 2,5.5 \mathrm{mmol} / 1 \mathrm{glu}-$ cose and a $\mathrm{pH}$ of 7.45. Amiloride was dissolved at a concentration of $100 \mathrm{~mol} / 1$ into the perfusion fluid. Perfusate collections were made after 3 hours and delivered into small, covered, pre-weighed polythene tubes. The uterine luminal fluid $\mathrm{pH}$ was measured using the HI8424 Portable $\mathrm{pH} / \mathrm{mV} /{ }^{\circ} \mathrm{C}$ Meter, which was purchased from HANNA Instrument, Singapore. Micro miniature $\mathrm{pH}$ probe (HANNA Instrument, Singapore) was connected to the $\mathrm{pH}$ meter and the $\mathrm{pH}$ of a minute volume of uterine fluid collected was directly measured.

\subsection{Protein Expression}

At the end of the treatment period, the rats were killed by cervical dislocation (procedure approved by local ethic committee) and the uterine horns and kidneys were immediately removed and proteins prepared for Western blotting analysis by homogenization in tissue lysis buffer (100 mM Tris pH 6.8, 1 mM EDTA pH 8.0, 10\% v/v glycerol and $10 \mathrm{ml} / 1$ protease inhibitor cocktail (Sigma, UK). Samples were subjected to centrifugation (5 min, $250 \mathrm{~g}$ ) to remove nuclei. Supernatants from each preparation were heated to $94^{\circ} \mathrm{C}$ for $5 \mathrm{~min}$ in denaturing buffer (Novex, Invitrogen UK). $30 \mathrm{mg}$ protein from the uterine and kidney samples were separated using Novex Bis-Tris gels (Invitrogen, UK). Fractionated proteins were transferred to nitrocellulose membrane (Biorad, UK) by electroblotting and immunostained with anti NHE-1 (Ab-Cam, UK) 1:500. Immunostained proteins were visualized by enhanced chemiluminescence (Amersham, UK) and exposure to auto-radiographic film. The size of immunostained proteins was calculated by comparison to protein size markers (BioRad, UK) on the same blots. For immunohisto-chemistry, uterine horns were fixed in $4 \%$ paraformaldehyde for $4 \mathrm{~h}$ at $4^{\circ} \mathrm{C}$. The tissues were then processed through to wax blocks and $5 \mathrm{~mm}$ sections cut. The sections were dewaxed in xylene and re-hydrated. The tissues were incubated in $10 \% \mathrm{H}_{2} \mathrm{O}_{2}$ in methanol to quench endogenous peroxidase activity and incubated overnight with primary antibodies (rat polyclonal $\mathrm{IgG}$ ) at the following concentrations in PBS; (1:10 for NHE-1) at $4^{\circ} \mathrm{C}$ in a humidified chamber. The tissues were then incubated with secondary antibody, bio-tinylated rabbit anti-rat IgG Amersham) at 1:500 for $1 \mathrm{~h}$ at room temperature and with tertiary antibody, streptavidin-horseradish peroxidase (Amersham) at 1:500 for $1 \mathrm{~h}$ at room temperature. The sites of antibody binding were visualized with DAB (Diamino-benzidine $\mathrm{HCl}$ ), which gave a dark-brown stain. The sections were coun- 
terstained with hematoxylin for nuclear staining.

\subsection{Statistical Analysis}

Data are expressed as means \pm SEM. Comparisons between groups of data were made with the Student t-test, with $\mathrm{P}<0.05$ considered to be statistically significant.

\section{RESULTS}

\subsection{The Effect of Amiloride on Uterine Fluid $\mathrm{pH}$}

In Figure 1, it was observed that the $\mathrm{pH}$ of the collected perfusates were basic for all treatment groups, despite the $\mathrm{pH}$ of the perfused solution being 7.45. The alkalinity however seems to differ between each treatment groups with the perfusate in progesterone treated group being the least alkaline $(\mathrm{pH} 8.20)(\mathrm{p}<0.05)$. No significant differences in $\mathrm{pH}$ were observed between the oestradiol $(\mathrm{pH} 8.55)$ and vehicle $(\mathrm{pH}$ 8.45) treated groups. Intraluminal administration of amiloride at $100 \mathrm{~m}$ significantly inhibits the reduction of $\mathrm{pH}$ in the progesterone treated group $(p<0.05)$, however not in the vehicle and oestradiol treated groups. The low perfusion rate at $1.5 \mathrm{l} / \mathrm{minute}$ provides adequate time for the action of amiloride on the folded luminal epithelium. In each experiment, the $\mathrm{pH}$ obtained was the mean $\mathrm{pH}$ of the collected fluid from both uteri in the same animal.

\subsection{Protein Expression}

Western blotting of protein isolated from rat uteri indicated the presence of NHE-1 protein in the uterus, and a protein of predicted size was detected in kidney. In the uterus, the immunostained NHE-1 protein product has a molecular weight of $95 \mathrm{kDa}$, which is similar to the product detected in kidney control samples (Figure 2). Immunohisto-chemistry indicated that NHE-1 protein was expressed mainly at the luminal epithelium under the influence of progesterone (Figures 3(c) and 3(e)). Little NHE-1 proteins were detected in the luminal epithelium after vehicle and oestradiol treatment (Figures 3(a) and 3(b)). NHE-1 was also present in a high amount in the glandular epithelia after progesterone treatment (Figure 3(c) and 3(e)). The intensity of immunoreactivity (as shown in Figure 3) and a quantitative assessment of the immunostaining for NHE-1 isoform are scaled from 0 with no staining to 4 to the most intense staining

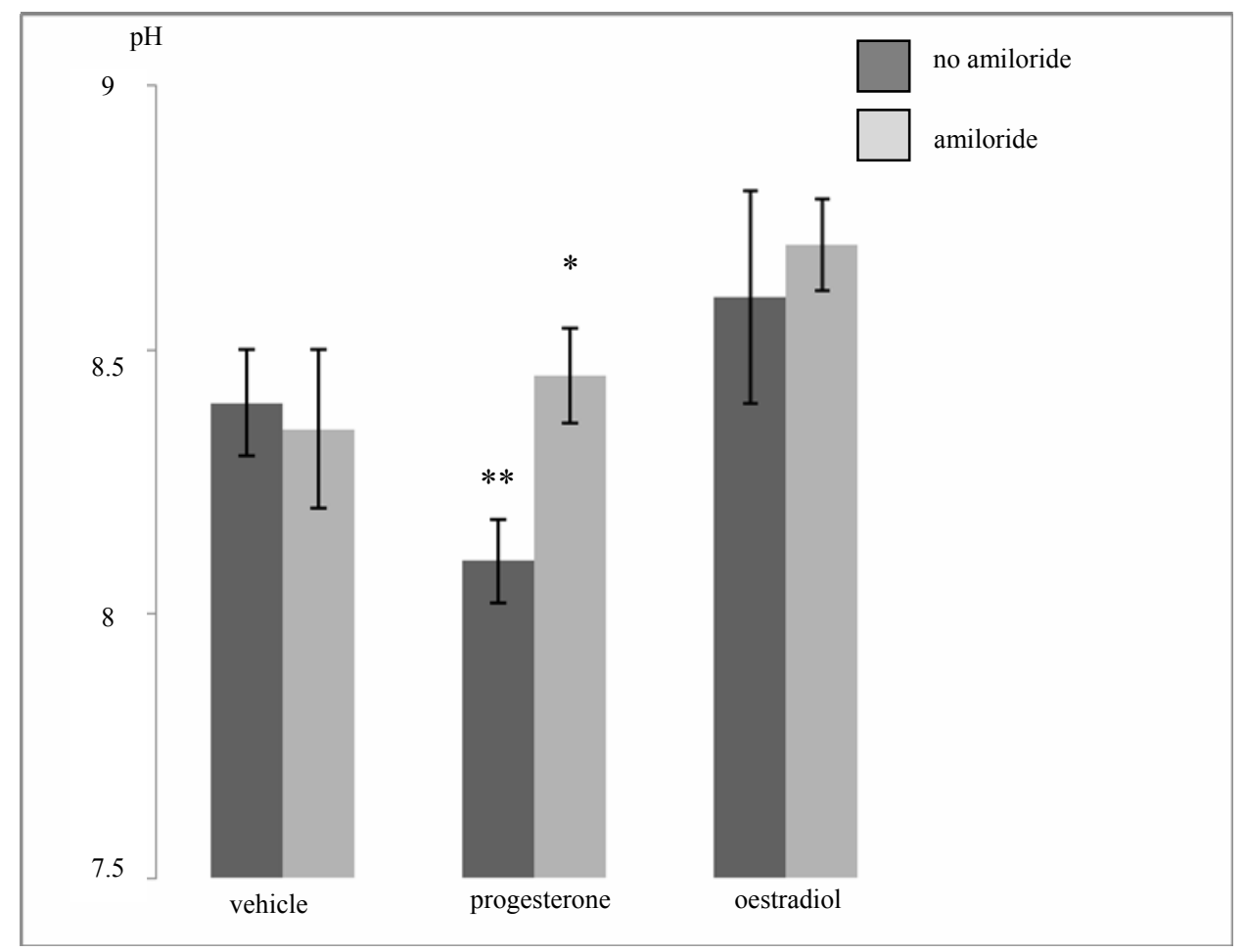

Figure 1. Comparison of the intraluminal fluid $\mathrm{pH}$ from the collected fluid between the vehicle, progesterone and oestradiol treatment respectively and the effect of amiloride on the fluid $\mathrm{pH}$ in each treatment groups (see Methods for detail). Each point represents the mean value $( \pm$ SEM) of each set of observations $(n=6$ rats per point). ${ }^{* *} \mathrm{p}<0.05$ (comparison between treatment groups in the absence of amiloride), ${ }^{*} \mathrm{p}<0.05$ (comparison between the presence and absence of amiloride in the progesterone-treated group). 


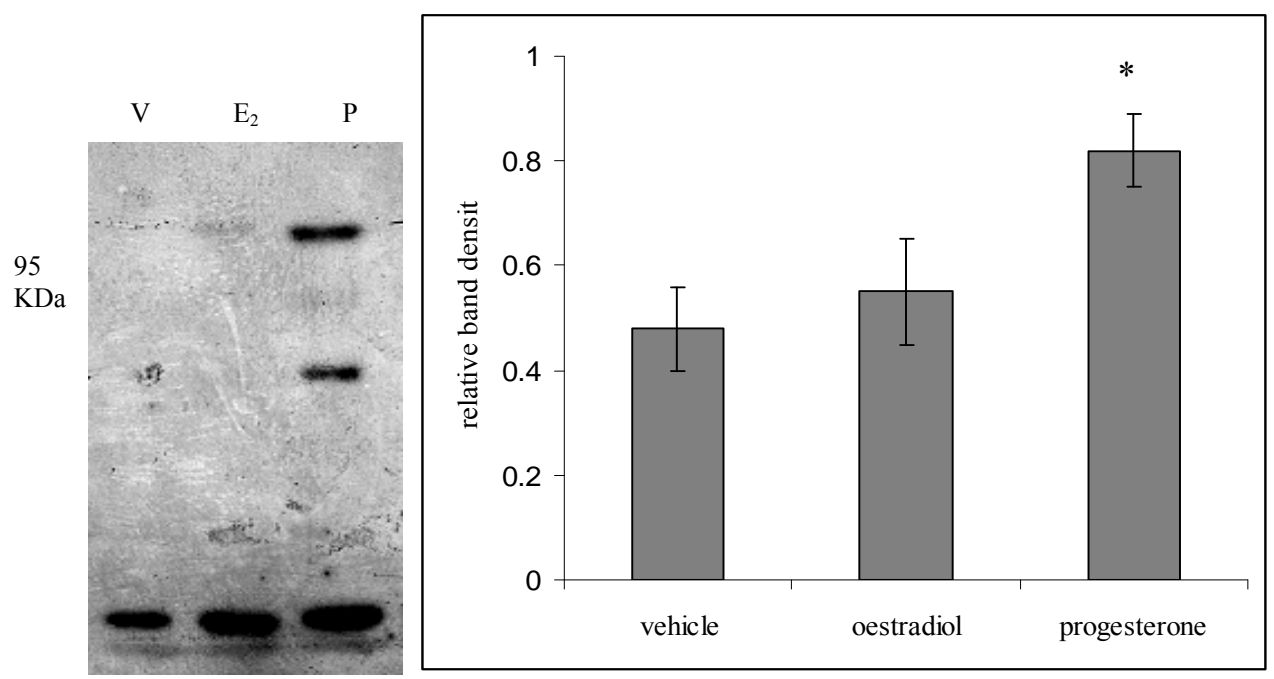

Figure 2. The effect of sex steroids treatment on NHE-1 protein expression in the uterus of ovariectomised rats. The picture above is a representative image of Western blotting analysis of protein expression under different steroid treatment, $\mathrm{C}$ for control, $\mathrm{P}$ for progesterone and $\mathrm{E}_{2}$ for oestradiol. The graph shows the analysis of the relative density for each band. Data were expressed as mean \pm S.E.M ( $n=3$ per treatment group. *indicates $\mathrm{p}<0.05$ as compared to $\mathrm{C}$ group for the particular band).

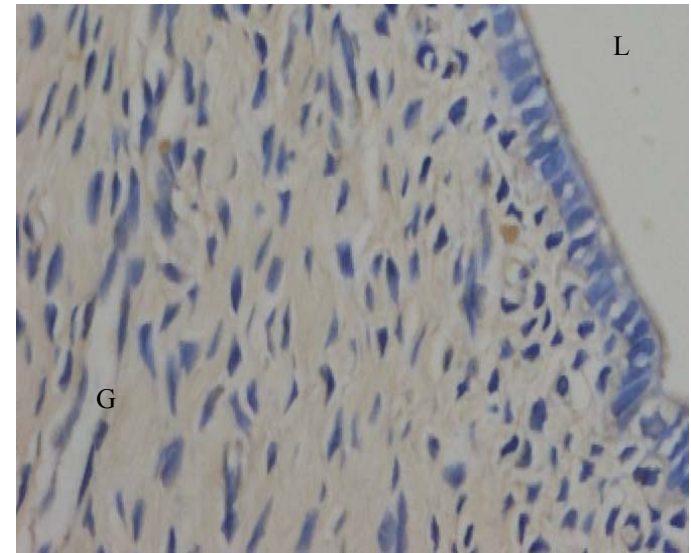

(a) Vehicle $(40 \times)$

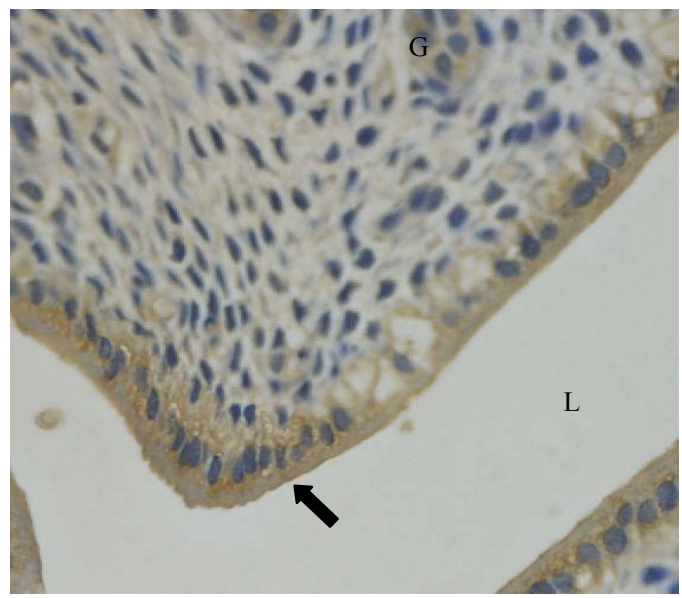

(c) Progesterone $(40 \times)$

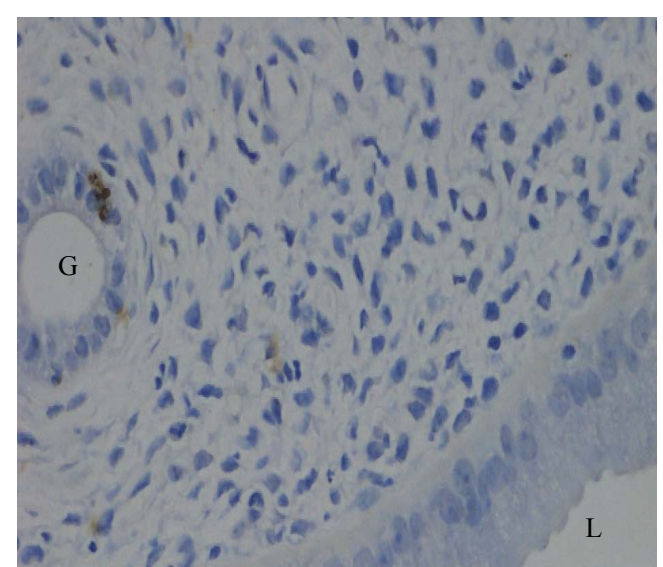

(b) Oestradiol $(40 \times)$

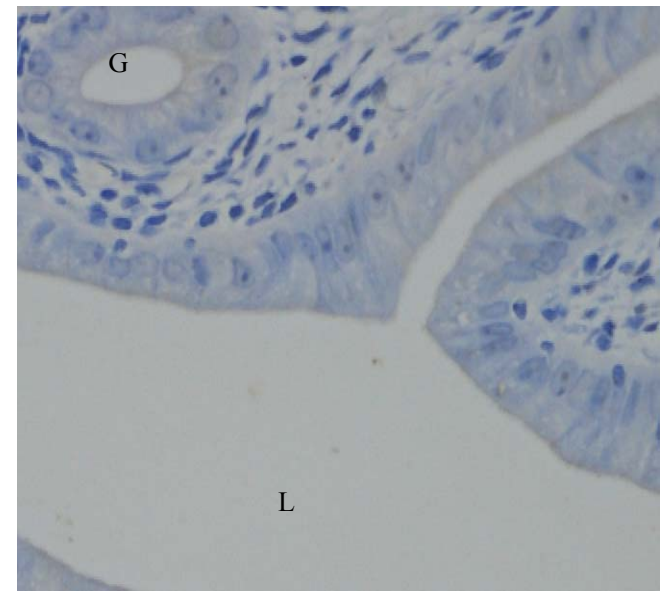

(d) Negative control $(40 \times)$ 


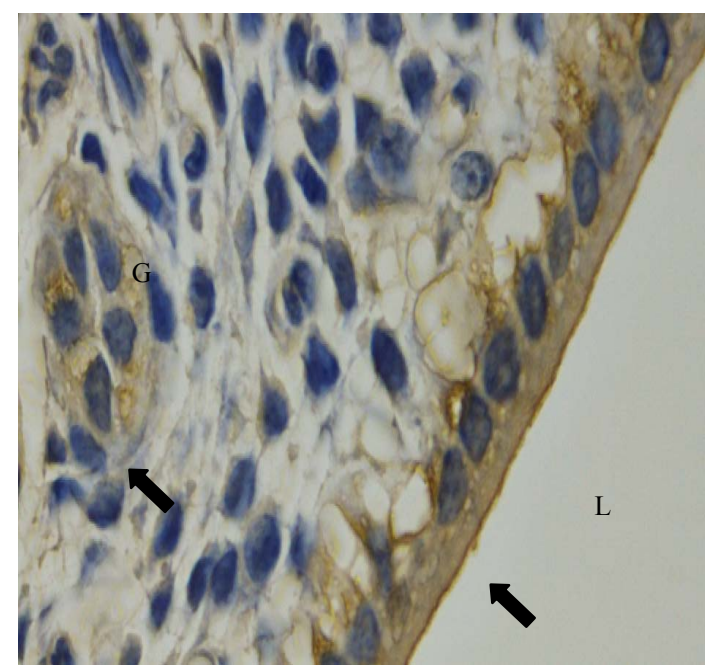

(e) Progesterone $(100 \times)$

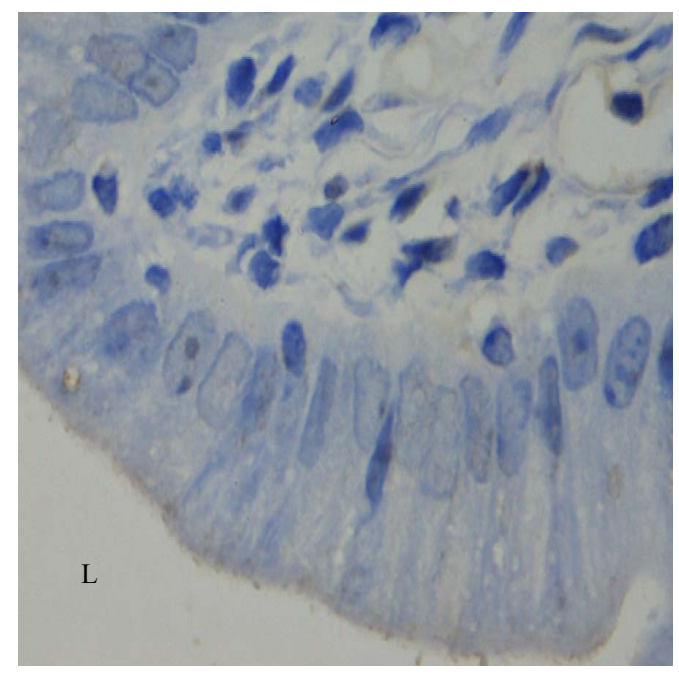

(f) Negative control $(100 \times)$

Figure 3. Immunohistochemical localization of NHE-1 in the uterus of (a) vehicle, (b) oestradiol- and (c) progesterone-treated ovariectomized rats. The pictures are representative images showing the distribution of NHE-1 in the luminal and glandular epithelia. Bound antibody is stained dark brown and marked with arrows $(\mathrm{n}=6$ animals per treatment group). The control image represents incubation without primary antibody, and the vehicle control represents uterine sections from non-steroid-treated ovariectomized animals. $\mathrm{G}=$ gland, $\mathrm{L}$ $=$ lumen. (a, b, c \& d are at $40 \times$ magnification, e $\&$ f are at $100 \times$ magnification).

Table 1. A semiquantitative assessment of immunostaining (DAB) of $\mathrm{Na}^{+} / \mathrm{H}^{+}$exchanger-1 in the luminal and glandular epithelia of rats' uterus.

\begin{tabular}{cccc}
\hline & Vehicle & Progesterone & Oestradiol \\
\hline luminal & 1 & 4 & 1 \\
glandular & 1 & 4 & 1 \\
\hline
\end{tabular}

as shown in Table 1.

\section{DISCUSSION}

The alkalinity of the uterine luminal fluid as observed in all the treatment groups is consistent with the previous reports that this fluid contains a high amount of $\mathrm{HCO}_{3}^{-}$ [25] which is essential for sperm capacitation and acrosomal reaction during fertilization [26]. Despite this fact, we have however observed a significant difference in the $\mathrm{pH}$ of the uterine fluid between the progesterone-treated groups and those rats receiving vehicle or oestradiol injections. Our findings indicated that progesterone reduces the alkalinity of the uterine luminal fluid. The significance of this $\mathrm{pH}$ reduction under progesterone mediated effect is not clear. A less alkaline environment could be important for embryo implantation that requires an elevated progesterone level [27] in a species such as rodents, in which implantation has been reported to occur 4 to 5 days after fertilization [28]. Furthermore, embryo-endometrial interaction is known to involve multiple factors such as a decrease in the thickness of the cell glycocalyx as well as cell surface charges [29,30]. In addition, there has been a reported loss of apico-basal polarity without a concurrent loss in cell adhesion molecules that allow interactions and attachment between the endometrium and the embryo [31]. The changes in the cell surface charges and polarity could be associated with the changes in the $\mathrm{pH}$ induced by a high level of progesterone during this phase.

Administration of amiloride, a non-specific $\mathrm{Na}^{+}$ channel blocker significantly inhibit $\mathrm{pH}$ reduction in the progesterone treated group but not the groups that were treated with vehicle or oestradiol. This suggests the presence of an amiloride-sensitive $\mathrm{Na}^{+}$channels at the apical surface of the endometrium of the progesterone treated rats. There is no significant changes in the luminal fluid in $\mathrm{pH}$ or volume in oestradiol or vehicle treated rats indicated that $\mathrm{Na}^{+}$channels were not present or present in too small an amount to exert a change in the uterine fluid environment under the regulation of oestradiol or without hormonal influence. Despite the presence of amiloride-sensitive $\mathrm{ENaC}$ which has been reported under the progesterone dominant state [18], however $\mathrm{ENaC}$ mediate luminal fluid loss without alteration of the luminal fluid $\mathrm{pH}$. This raises suspicion that other amiloride-sensitive $\mathrm{Na}^{+}$channels such as the NHE may be involved.

The presence of NHE-1 in the endometrium in the progesterone-treated group was further confirmed by Western blotting and immunohistochemistry. NHE-1 
was localized in the cytoplasm and brush border of the luminal epithelial cells as well as in the glandular epithelia. The apical distribution of NHE-1 in the endometrium is similar to those seen in the rats kidney, jejunum and colon [32]. In the rats cecum however, NHE-1 and NHE-3 are found only on the brush border cells lining the apical surface [33]. In addition to maintaining intracellular $\mathrm{pH}$ homeostasis, NHE could also be involved in uterine luminal fluid volume regulation. This has been reported to occur in the epididymis whereby despite the absence of $\mathrm{ENaC}$, NHE is responsible for most of seminal fluid reabsorption [17].

We concluded that progesterone induces the expression of NHE-1 in the endometrial epithelial cells. This protein could be involved in $\mathrm{pH}$ regulation of the uterine luminal fluid thus creating an environment that is suitable for a successful implantation. The understanding of a molecular mechanism regulating uterine fluid $\mathrm{pH}$ is of clinical relevance because this may lead to strategies to correct implantation failure and to improve pregnancy rates. In addition, this could also help in identifying a new marker for the period of uterine receptivity. However more works need to be done to confirm the involvement of NHE in uterine fluid $\mathrm{pH}$ regulation despite of a limited data available from our study.

\section{ACKNOWLEDGEMENT}

This project is supported by the FRGS grant, Ministry of Higher Education Malaysia.

\section{REFERENCES}

[1] Henriquez, S., Tapia, A., Quezada, M., Vargas, M., Cardenas, H., Rios, M., Salvatierra, A.M., Croxatto, H., Orihuela, P., Zegers-Hochschild, F., Munroe, D.J. and Velasquez, L. (2006) Deficient expression of monoamine oxidase $\mathrm{A}$ in the endometrium is associated with implantation failure in women participating as recipients in oocyte donation. Journal of Molecular Human Reproduction, 12, 749-754. doi:10.1093/molehr/gal082

[2] Martin, L., Finn, C.A. and Carter, J. (1970) Effects of progesterone and oestradiol on the luminal epithelium of the mouse uterus. Journal of Reproduction \& Fertility, 21, 461-469. doi:10.1530/jrf.0.0210461

[3] Hoversland, R.C. and Weitlauf, H.M. (1981) The volume of uterine fluid in implanting and delayed implanting mice. Journal of Reproduction \& Fertility, 62, 105-109. doi:10.1530/jrf.0.0620105

[4] Shaw, S.T., Jr., Azar, E. and Moyer, D.L. (1975) $3 \mathrm{H}_{2} \mathrm{O}$ volume and exchange in uterine cavity of monkeys. American Journal of Physiology, 229, 1465-1470.

[5] Nikas, G. and Makrigiannakis, A. (2003) Endometrial pinopodes and uterine receptivity. Annals of the New York Academy of Sciences, 997, 120-123. doi:10.1196/annals.1290.042
[6] Lindsay, L.A. and Murphy, C.R. (2004) Redistribution of aquoporins in uterine epithelial cells at the time of implantation in the rat. Acta Histochemica, 106, 229-307. doi:10.1016/j.acthis.2004.05.004

[7] Lindsay, L.A. and Murphy, C.R. (2006) Redistribution of aquoporins 1 and 5 in the rat uterus is dependent on progesterone: a study with light and electron microscopy. Reproduction, 131, 369-378. doi:10.1530/rep.1.00914

[8] Chan, L.N., Tsang, L.L., Rowlands, D.K., Rochelle, L.G., Boucher, R.C. and Chan, H.C. (2002) Distribution and regulation of ENaC subunit and CFTR mRNA expression in murine female reproductive tract. Journal of Membrane Biology, 185, 165-176. doi:10.1007/s00232-001-0117-y

[9] Quinn, C.E. and Casper, R.F. (2009) Pinopodes: A questionable role in endometrial receptivity. Human Reproduction Update, 15, 229-236.

[10] Vishwakarma, P. (1962) The $\mathrm{pH}$ and bicarbonate-ion content of the oviduct and uterine fluids. Fertility and Sterility, 13, 481-485.

[11] Chan, H.C., Shi, Q.X., Zhou, C.X., Wang, X.F., Xu, W.M., Chen, W.Y., Chen, A.J., Ni, Y. and Yuan, Y.Y. (2006) Critical role of CFTR in uterine bicarbonate secretion and the fertilizing capacity of sperm. Molecular and Cellular Endocrinology, 250, 106-113. doi:10.1016/j.mce.2005.12.032

[12] Hug, M.J., Tamada, T. and Bridges, R.J. (2003) CFTR and Bicarbonate secretion to epithelial cells. News in Physiological Sciences, 18, 38-42.

[13] Ogata, T. (2006) Bicarbonate secretion by rat bile duct brush cells indicated by immunohistochemical localization of CFTR, anion exchanger $\mathrm{AE} 2, \mathrm{Na}^{+} / \mathrm{HCO}_{3}^{-}$cotransporter, carbonic anhydrase II, $\mathrm{Na}^{+} / \mathrm{H}^{+}$exchangers NHE1 and NHE3, $\mathrm{H}^{+} / \mathrm{K}^{+}$-ATPase, and $\mathrm{Na}^{+} / \mathrm{K}^{+}$-ATPase. Medical Molecular Morphology, 39, 44-48. doi:10.1007/s00795-006-0312-0

[14] Grinstein, S., Woodside, M., Waddell, T.K., Downey, G.P., Orlowski, J., Pouyssegur, J., Wong, D.C. and Foskett, J.K. (1993) Focal localization of the NHE-1 isoform of the $\mathrm{Na}^{+} / \mathrm{H}^{+}$antiport: assessment of effects on intracellular $\mathrm{pH}$. EMBO Journal, 12, 5209-5218.

[15] Chambrey, R., Warnock, D.G., Podevin, R.A., Bruneval, P., Mandet, C., Belair, M.F., Bariety, J. and Paillard, M. (1998) Immunolocalization of the $\mathrm{Na}^{+} / \mathrm{H}^{+}$exchanger isoform NHE2 in rat kidney. Journal of Physiology, 275, F379-F386.

[16] Argent, B.E. (1994) Case RM pancreatic duct-cellular mechanism and control of bicarbonate secretion. In: Johnson L.R., Ed., Physiology of the Gastrointestinal Tract, 3rd Edition, Raven Press, New York, 1397-1473.

[17] Leung, G.P., Tse, C.M., Chew, S.B. and Wong, P.Y. (2001) Expression of multiple $\mathrm{Na}+\mathrm{H}+$ exchanger isoforms in cultured epithelial cells from rat efferent duct and cauda epididymidis. Biology of Reproduction, 64, 482-490. doi:10.1095/biolreprod64.2.482

[18] Salleh, N., Baines, D.L., Naftalin, R.J. and Milligan, S.R. (2005) The hormonal control of uterine luminal fluid secretion and absorption. Journal of Membrane Biology, 206, 17-28. doi:10.1007/s00232-005-0770-7

[19] Crljen, V., Sabolić, I., Susac, J., Appenroth, D., HerakKramberger, C.M., Ljubojević, M., Anzai, N., Antolović, R., Burckhardt, G., Fleck, C. and Sabolić, I. (2005) Im- 
munocytochemical characterization of the incubated rat renal cortical slices. Pflugers Archiv Jul, 450, 269-279.

[20] Hoogerwerf, W.A., Tsao, S.C., Devuyst, O., Levine, S.A., Yun, C.H., Yip, J.W., Cohen, M.E., Wilson, P.D., Lazenby, A.J., Tse, C.M. and Donowitz, M. (1996) NHE2 and NHE3 are human and rabbit intestinal brush-border proteins. American Journal of Physiology, 270, G29-G41.

[21] Broere, N., Chen, M., Cinar, A., Singh, A.K., Hillesheim, J., Riederer, B., Lünnemann, M., Rottinghaus, I., Krabbenhöft, A., Engelhardt, R., Rausch, B., Weinman, E.J., Donowitz, M., Hubbard, A., Kocher, O., de Jonge, H.R., Hogema, B.M. and Seidler, U. (2009) Defective jejunal and colonic salt absorption and altered $\mathrm{Na}(+) / \mathrm{H}(+)$ exchanger 3 (NHE3) activity in NHE regulatory factor 1 (NHERF1) adaptor protein-deficient mice. Pflugers Archiv, 457, 1079-1091.

[22] Clemetson, C.A.B., Kim, J.K., Mallikarjuneswara, V.R. and Wilds, J.H. (1972) The sodium and potassium concentrations in the uterine fluid in the rat at the time of implantation. Journal of Endocrinology, 54, 417-423. doi:10.1677/joe. 0.0540417

[23] Casslen, B. and Nilsson, B. (1984) Human uterine fluid, examined in undiluted samples for osmolarity and the concentrations of inorganic ions, albumin, glucose, and urea. American Journal of Obstetrics and Gynecology, 150, 877-881.

[24] Nordenvall, M., Ulmsten, U. and Ungerstedt, U. (1989) Influence of progesterone on the sodium and potassium concentrations of rat uterine fluid investigated by microdialysis. Gynea Obstet Invest, 28, 73-77. doi: $10.1159 / 000293518$

[25] Murdoch, R.N. and White, I.G. (1968) The influence of the female genital tract on the metabolism of rabbit spermatozoa. II. Effect of storage with glucose, lactate, bicarbonate, and female genital tract fluids. Australian Journal of Biological Sciences, 21, 973-980.
[26] Boatman, D.E. and Robbins, R.S. (1991) Bicarbonate: carbon-dioxide regulation of sperm capacitation, hyperactivated motility, and acrosome reactions. Biology of Reproduction, 44, 806-813. doi:10.1095/biolreprod44.5.806

[27] Song, H., Han, K. and Hyunjung, L.H. (2007) Progesterone supplementation extends uterine receptivity for blastocyst implantation in mice. Reproduction, 133, 487-493. doi:10.1530/REP-06-0330

[28] Abrahamsohn, P.A. and Zorn, T.M. (1993) Implantation and decidualization in rodents. Journal of Experimental Zoology, 266, 603-628. doi:10.1002/jez.1402660610

[29] Aplin, J.D. (1999) MUC-1 glycosylation in endometrium: possible roles of the apical glycocalyx at implantation. Human Reproduction, 14, 17-25.

[30] Niklaus, A.L., Murphy, C.R. and Lopata, A. (2001) Characteristics of the uterine luminal surface epithelium at preovulatory and preimplantation stages in the marmoset monkey. Anat Rec, 264, 82-92. doi:10.1002/ar.1124

[31] Thie, M., Harrach-Ruprecht, B., Sauer, H., Fuchs, P., Albers, A. and Denker, H.W. (1995) Cell adhesion to the apical pole of epithelium: a function of cell polarity. European Journal of Cell Biology, 66, 180-191.

[32] Khan, I., Thomas, N. and Haridas, S. (2001) Expression and subcellular localization of the sodium hydrogen exchanger isoform 1 in rat tissues: A possible functional relevance. Molecular and Cellular Biochemistry, 219, 153-161. doi:10.1023/A:1010867631953

[33] Okamoto, K., Hanazaki, K., Akimori, T., Okabayashi, T., Okada, T., Kobayashi, M. and Ogata, T. (2008) Immunohistochemical and electron microscopic characterization of brush cells of the rat cecum. Medical Molecular Morphology, 41, 145-150. doi:10.1007/s00795-008-0412-0 